\title{
Stereoselective synthesis of 4-0xo-2,5-dienes and conjugated dienes by Stille cross coupling reactions of vinylstannanes
}

\author{
Pablo M. Fidelibus, ${ }^{\text {a,b }}$ Darío C. Gerbino ${ }^{\text {a,b }}$ Sandra D. Mandolesi, ${ }^{\text {a* }}$ \\ and Julio C. Podestáa ${ }^{a, b_{*}}$ \\ ${ }^{a}$ Instituto de Investigaciones en Quimica Organica, Departamento de Quimica, Universidad \\ Nacional del Sur, Avda. Alem 1253, 8000 Bahia Blanca, Argentina. \\ ${ }^{b}$ Consejo Nacional de Investigaciones Cientificas y Tecnicas (CONICET), Buenos Aires, \\ Argentina \\ E-mail:jpodesta@uns.edu.ar
}

\section{Dedicated to Professor Joan Bosch on his $60^{\text {th }}$ birthday}

\begin{abstract}
The palladium-catalyzed cross coupling reactions between trineophylstannylvinyl esters and unsaturated acyl chlorides lead mostly to 4-oxo-2,5-dienes in good yields (60-77\%). In some cases homocoupling products are also formed. On the other hand, the Stille reaction of Z-di- and trisubstituted vinyl iodides with trineophylvinylstannanes enables the synthesis of polysubstituted butadienes in moderate to good yields (40-60\%).
\end{abstract}

Keywords: Vinyltrineophylstannanes, unsaturated acyl chlorides, Stille reaction, 4-oxo-2,5dienes, polysubstituted butadienes

\section{Introduction}

The Stille reaction, i.e., the palladium-catalyzed cross coupling reaction between organic halides and organostannanes, is one of the more important methods used to make carbon-carbon bonds. ${ }^{1}$ A significant feature of this reaction is that the organotins can be prepared with a wide range of transferable substituents many of which are unavailable using nucleophilic reagents like Grignard, organolithium, and organozinc reagents. Also, the organotin reagents usually employed are air- and moisture-stable. Although numerous applications of the Stille reaction have been reported in recent years, only few examples of palladium-catalyzed cross-couplings involving acyl chlorides can be found in the literature. ${ }^{2}$ 4-oxo-2,5-diene structural units are of particular interest due to their possible use as intermediates in the synthesis of natural products. 
They are also part of antitumor molecules like melodienone and homoisomelodienone, two cytotoxic agents isolated from the Melodrum fruticosum Lour (Anonaceae from southeast Asia). ${ }^{3}$

On the other hand, we have been engaged for some time in the synthesis of vinylstannanes with well defined stereochemistry containing organotin moieties with bulky organic ligands specially neophyl groups. ${ }^{4}$ These trineophyltin derivatives have been obtained with good to excellent yields via free radical and palladium catalyzed hydrostannation of mono- and disubstituted alkynes. It should be noted that the viniltrineophylstannanes are more stable than their trimethyl- and tributyltin analogues which have been reported to decompose or isomerize during the chromatographic purification. ${ }^{4 b}$

In this paper, we wish to report some results we have obtained in studies related to the palladium-catalyzed cross coupling reactions between trineophylstannylvinyl esters and unsaturated acyl chlorides as well as to the couplings between some vinyliodides and vinylstannanes carried out in order to determine their possible use in the synthesis of 4-oxo-2,5dienes and of conjugated dienes respectively.

\section{Results and Discussion}

The Stille reaction between $\alpha, \beta$-unsaturated acyl chlorides and trineophylstannylvinyl esters was carried out according to Scheme 1. The two vinylstannanes used were selected taking into account that they have been obtained in quantitative yields via hydrostannation of the corresponding substituted alkynes. ${ }^{4 \mathrm{a}, \mathrm{e}}$

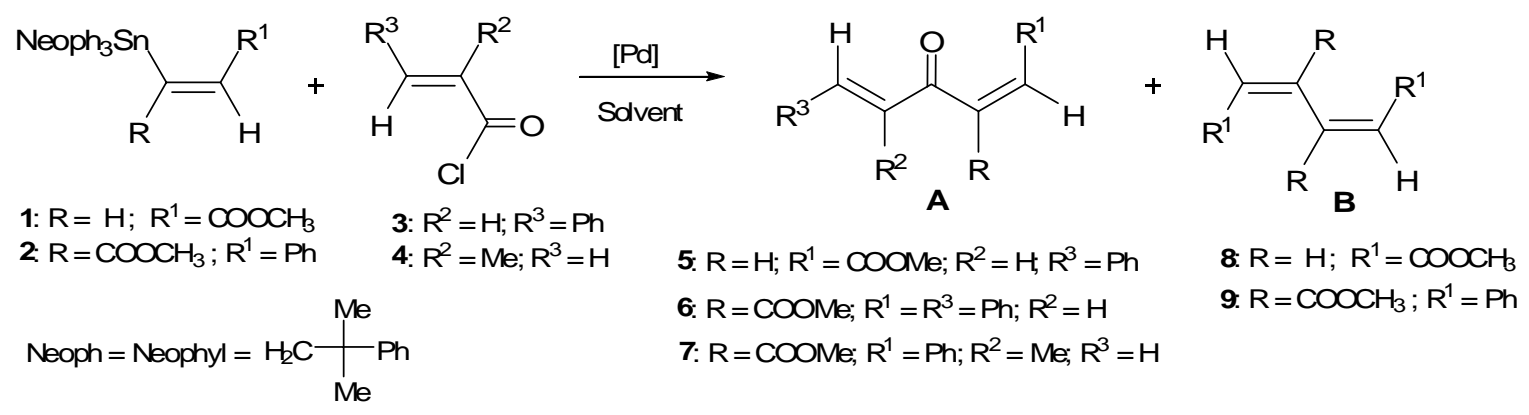

\section{Scheme 1}

The reactions were carried out using $\mathrm{Pd}\left(\mathrm{PPh}_{3}\right)_{4} / \mathrm{THF}$ and $\mathrm{Pd}\left(\mathrm{PPh}_{3}\right)_{2} \mathrm{Cl}_{2} / \mathrm{DMF}$ as catalyst/solvent systems and at a moderate temperature $\left(65^{\circ} \mathrm{C}\right)$.

As shown in Table 1, we found that whereas the reaction between methyl (Z)-3trineophylstannylpropenoate (1) and (E)-3-phenylpropenoyl chloride (3) mediated by $\left.\mathrm{Pd}_{(\mathrm{PPh}}\right)_{4}$ (entry 1) leads to the expected acylation product 5 , this reaction does not take place using $\mathrm{Pd}\left(\mathrm{PPh}_{3}\right)_{2} \mathrm{Cl}_{2}$ (entry 2) as catalyst. The homocoupling product 8 (entry 1 ) results from a common side reaction of the vinylstannane $\mathbf{1}$ observed in many Stille couplings. ${ }^{1 \mathrm{~b}}$ In Table 1 it is also 
shown that the vinylstannane 1 does not react with methacroyl chloride (4) when the catalyst is $\mathrm{Pd}\left(\mathrm{PPh}_{3}\right)_{4}$ (entry 3) and that when the reaction is carried out in the presence $\mathrm{Pd}\left(\mathrm{PPh}_{3}\right)_{2} \mathrm{Cl}_{2}$ (entry 4) the only product obtained is $\mathbf{8}$, i.e., the homocoupling product in $60 \%$ yield.

Table 1. Products obtained in the palladium catalyzed acylation of vinyltin compounds

\begin{tabular}{|c|c|c|c|c|c|c|c|}
\hline \multirow{2}{*}{$\begin{array}{l}\text { Entry } \\
\mathrm{N}^{\mathrm{o}}\end{array}$} & \multirow[t]{2}{*}{$\mathrm{VT}^{\mathrm{a}}$} & \multirow[t]{2}{*}{$\mathrm{AC}^{\mathrm{b}}$} & \multirow[t]{2}{*}{ Catalyst/Solvent ${ }^{\mathrm{c}}$} & \multirow{2}{*}{$\begin{array}{l}\text { Time } \\
\text { (h) }\end{array}$} & \multicolumn{2}{|c|}{ Products of: } & \multirow{2}{*}{$\begin{array}{l}\text { Yield } \\
\text { (\%) }\end{array}$} \\
\hline & & & & & $\begin{array}{c}\text { Coupling } \\
(\%)\end{array}$ & $\begin{array}{c}\text { Homocoupling } \\
(\%)\end{array}$ & \\
\hline 1 & 1 & 3 & $\mathrm{Pd}\left(\mathrm{PPh}_{3}\right)_{4} / \mathrm{THF}$ & 72 & $5(65)$ & $8(35)$ & 70 \\
\hline 2 & 1 & 3 & $\mathrm{Pd}\left(\mathrm{PPh}_{3}\right)_{2} \mathrm{Cl}_{2} / \mathrm{DMF}$ & 76 & - & - & d \\
\hline 3 & 1 & 4 & $\mathrm{Pd}\left(\mathrm{PPh}_{3}\right)_{4} / \mathrm{THF}$ & 96 & - & - & d \\
\hline 4 & 1 & 4 & $\mathrm{Pd}\left(\mathrm{PPh}_{3}\right)_{2} \mathrm{Cl}_{2} / \mathrm{DMF}$ & 48 & - & $8(100)$ & 60 \\
\hline 5 & 2 & 3 & $\mathrm{Pd}\left(\mathrm{PPh}_{3}\right)_{4} / \mathrm{THF}$ & 72 & $6(100)$ & - & 63 \\
\hline 6 & 2 & 3 & $\mathrm{Pd}\left(\mathrm{PPh}_{3}\right)_{2} \mathrm{Cl}_{2} / \mathrm{DMF}$ & 12 & $6(80)$ & $9(20)$ & 75 \\
\hline 7 & 2 & 4 & $\mathrm{Pd}\left(\mathrm{PPh}_{3}\right)_{4} / \mathrm{THF}$ & 24 & $7(100)$ & - & 77 \\
\hline 8 & 2 & 4 & $\mathrm{Pd}\left(\mathrm{PPh}_{3}\right)_{2} \mathrm{Cl}_{2} / \mathrm{DMF}$ & 72 & $7(100)$ & - & 62 \\
\hline
\end{tabular}

${ }^{\mathrm{a}} \mathrm{VT}=$ Vinyltin compound. ${ }^{\mathrm{b}} \mathrm{AC}=$ Acyl chloride. ${ }^{\mathrm{c}}$ Catalyst/solvent ratio relationships used: VT $=1$ eq; $\mathrm{AC}=1 \mathrm{eq}$; Catalyst: $0.01 \mathrm{eq}$; solvent $=5 \mathrm{ml} .{ }^{\mathrm{d}}$ Starting material recovered.

On the other hand, the reaction of methyl (Z)-2-trineophylstannyl-3-phenylpropenoate (2) with acid chlorides 3 and 4 using both $\mathrm{Pd}\left(\mathrm{PPh}_{3}\right)_{4}$ and $\mathrm{Pd}\left(\mathrm{PPh}_{3}\right)_{2} \mathrm{Cl}_{2}$ as catalysts (Table 1, entries 5-8), leads to compounds 6 and 7 as the major (entry 6) or the only (entries 5,7, and 8) products in the four cases studied. Again, in one case (entry 6) it was observed the formation of homocoupling product, i.e., compound 9.

These results seem to indicate that the success of the acylation of vinylstannanes with unsaturated acid chlorides catalyzed by palladium complexes, depends mostly on the structural features of the stannanes. It is to add that the new 4-oxo-2,5-dienes 5-7 were obtained with complete regio- and stereoselectivity.

Taking into account that the starting vinylstannanes had been obtained in quantitative yields, the global yield of this two steps synthesis of 4-oxo-2,5-dienes is around 65\%. In the literature, only a six steps synthesis that leads in $27 \%$ global yield to methyl $(E, E)-6$-phenyl-4-oxo-2,5hexadienoate, i.e., the geometric isomer of $(Z, E)-5$ has been described. ${ }^{\text {3a }}$

Conjugated dienes with a well defined stereochemistry are very interesting structures. Many aliphatic natural products contain two or three conjugated double bonds whose geometry is directly connected with the biologic activity of these compounds. We considered it possible to carry out the synthesis of these conjugated systems starting from vinylstannanes via a two step sequence involving a iodo destannylation followed by a Stille cross couplings, according to Scheme 2. 


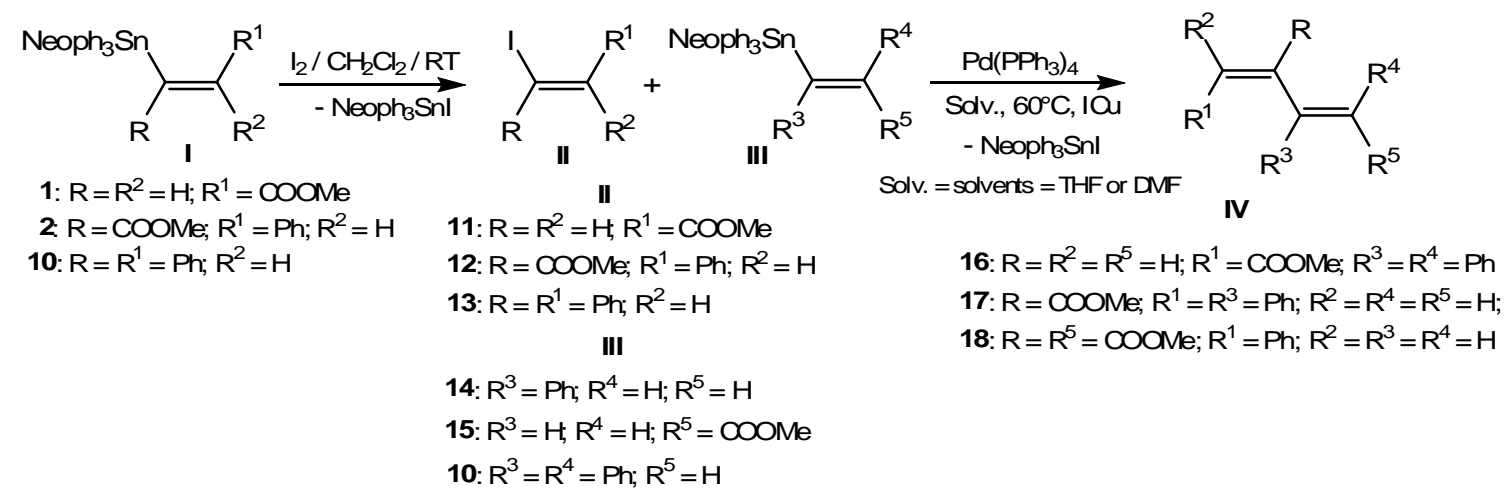

\section{Scheme 2}

Type II iodides are difficult to obtain following other synthetic routes because they are prone to isomerization in the reaction media usually employed for their preparation. ${ }^{5}$ As shown in Scheme 2, iodination in $\mathrm{CH}_{2} \mathrm{Cl}_{2}$ at room temperature of vinylstannanes $\mathbf{1}, \mathbf{2}$, and $\mathbf{1 0}$ leads to the iodides 11-13 in almost quantitative yield after being purified by column chromatography on silicagel 60.

Table 2. Results obtained in the synthesis of conjugated dienes

\begin{tabular}{cccccccccc}
\hline Entry & Type & $\mathrm{Nr}$ & $\mathrm{R}$ & $\mathrm{R}^{1}$ & $\mathrm{R}^{2}$ & $\mathrm{R}^{3}$ & $\mathrm{R}^{4}$ & $\mathrm{R}^{5}$ & $\begin{array}{c}\text { Yield } \\
(\%)\end{array}$ \\
\hline 1 & I & $\mathbf{1}$ & $\mathrm{H}$ & COOMe & $\mathrm{H}$ & - & - & - & $100^{4 \mathrm{a}}$ \\
2 & I & $\mathbf{2}$ & COOMe & $\mathrm{Ph}$ & $\mathrm{H}$ & - & - & - & $100^{4 \mathrm{a}}$ \\
3 & I & $\mathbf{1 0}$ & $\mathrm{Ph}$ & $\mathrm{Ph}$ & $\mathrm{H}$ & - & - & - & $100^{4 \mathrm{a}}$ \\
4 & II & $\mathbf{1 1}$ & $\mathrm{H}$ & COOMe & $\mathrm{H}$ & - & - & - & 100 \\
5 & II & $\mathbf{1 2}$ & $\mathrm{COOMe}$ & $\mathrm{Ph}$ & $\mathrm{H}$ & - & - & - & 100 \\
6 & II & $\mathbf{1 3}$ & $\mathrm{Ph}$ & $\mathrm{Ph}$ & $\mathrm{H}$ & - & - & - & 100 \\
7 & III & $\mathbf{1 4}$ & - & - & - & $\mathrm{Ph}$ & $\mathrm{H}$ & $\mathrm{H}$ & $99^{4 \mathrm{a}}$ \\
8 & III & $\mathbf{1 5}$ & - & - & - & $\mathrm{H}$ & $\mathrm{H}$ & $\mathrm{COOMe}$ & $100^{4 \mathrm{a}}$ \\
9 & IV & $\mathbf{1 6}$ (from 11+10) & $\mathrm{H}$ & $\mathrm{COOMe}$ & $\mathrm{H}$ & $\mathrm{Ph}$ & $\mathrm{Ph}$ & $\mathrm{H}$ & 40 \\
10 & IV & $\mathbf{1 7}$ (from 12+14) & COOMe & $\mathrm{Ph}$ & $\mathrm{H}$ & $\mathrm{Ph}$ & $\mathrm{H}$ & $\mathrm{H}$ & 62 \\
11 & IV & $\mathbf{1 8}$ (from 13+ 15) & COOMe & $\mathrm{Ph}$ & $\mathrm{H}$ & $\mathrm{H}$ & $\mathrm{H}$ & $\mathrm{COOMe}$ & 45 \\
\hline
\end{tabular}

We then carried out the study on the cross coupling reactions mediated by palladium complexes between iodides 11-13 and type III vinyl stannanes according to Scheme 2. These reactions lead with moderate yields and with complete stereoselectivity to the dienes $\mathbf{1 6 - 1 8}$, as shown in Table 2. Only vinyl iodides $\mathbf{1 1}$ and $\mathbf{1 2}$ could be used because iodide $\mathbf{1 3}$ decomposed under the reaction conditions, probably due to the temperature needed in order to effect the coupling. ${ }^{5}$ We found that in order to obtain the desired coupling products in reasonable yields, the best catalyst/solvent system was $\mathrm{Pd}\left(\mathrm{PPh}_{3}\right)_{4}$ / ICu / DMF. With the other systems studied, 
$\mathrm{Cl}_{2} \mathrm{Pd}\left(\mathrm{PPh}_{3}\right)_{2} / \mathrm{DMF}, \mathrm{Pd}\left(\mathrm{PPh}_{3}\right)_{4} / \mathrm{THF}$, and $\mathrm{Cl}_{2} \mathrm{Pd}\left(\mathrm{PPh}_{3}\right)_{2} / \mathrm{THF}$ the yields obtained were very low.

Taking into account that the starting vinylstannanes had been obtained in quantitative yields, the global yield of this three steps synthesis of the 1,3-dienic systems is of about $45 \%$.

Further studies on the application of the cross couplings reactions mediated by palladium complexes to the stereoselective synthesis of insaturated conjugated systems are in advance.

\section{Conclusions}

The results reported in this paper suggest that by an adequate selection of the experimental parameters it is possible to obtain 4-oxo-2,5-dienes and conjugated dienes via palladium cross coupling reactions. These compounds were obtained in good to fair yields and with complete stereoselectivity. According to the catalyst/solvent system employed, some products of homocoupling of the starting vinyl stannanes were also obtained in some cases.

\section{Experimental Section}

General Procedures. NMR spectra were obtained in a Bruker ARX 300 instrument. Infrared spectra were recorded with a Nicolet Nexus FT spectrometer. Mass spectra were obtained using a Finnigan MAT Model 8230 at Dortmund University (Germany). Microanalyses were performed at Dortmund University. All the solvents, catalysts, and reagents used were analytical reagent grade.

\section{Stille reactions between $\alpha, \beta$-unsaturated acyl chlorides and trineophylstannylvinyl esters}

All the reactions were carried out following the same procedure. One experiment is described in detail to illustrate the method used.

Synthesis of methyl (2E,4E)-2-benzylidene-3-oxo-5-phenylpent-4-enoate (6). To a solution of vinyl stannane 2 (0.42 g, $0.70 \mathrm{mmol}$ ) and 3-phenylpropenoyl chloride (3) (0.12 g, $0.70 \mathrm{mmol})$ in dry THF $(8 \mathrm{~mL})$ under argon atmosphere was added $\mathrm{Pd}\left(\mathrm{PPh}_{3}\right)_{4}(0.07 \mathrm{mmol})$ and the mixture was stirred at $65{ }^{\circ} \mathrm{C}$. The progress of the reaction was monitored by TLC. Then, the reaction mixture was treated with saturated aqueous $\mathrm{NaCl}(8 \mathrm{~mL})$ and the aqueous phase was separated and extracted with diethyl ether $(3 \times 3 \mathrm{~mL})$. The combined organic extracts were dried with anhydrous $\mathrm{MgSO}_{4}$, filtered and the solvent was eliminated under reduced pressure. The oily residue was purified by column chromatography on silica gel $60\left(\mathrm{Et}_{2} \mathrm{O}-\mathrm{Hexane,} \mathrm{1:99)}\right.$ to give 6 (0.15 g, 0.44 mmol, 63\%). IR (KBr, film, $\mathrm{cm}^{-1}$ ): 3056; 3029; 2970; 1720; 1635; 1495; 1437; 1333; 1312; 765; 699. ${ }^{1} \mathrm{H}-\mathrm{NMR}\left(\mathrm{CDCl}_{3}\right) \delta \mathrm{ppm}: 3.77$ (s, 3H), $6.77\left(\mathrm{~d},{ }^{3} \mathrm{~J}(\mathrm{H}, \mathrm{H})=15.4 \mathrm{~Hz}, 1 \mathrm{H}\right)$, 7.15-7.42 (m, 10H), $7.54\left(\mathrm{~d},{ }^{3} \mathrm{~J}(\mathrm{H}, \mathrm{H})=15.4 \mathrm{~Hz}, 1 \mathrm{H}\right), 7.83(\mathrm{~s}, 1 \mathrm{H}) .{ }^{13} \mathrm{C}-\mathrm{NMR}\left(\mathrm{CDCl}_{3}\right) \delta \mathrm{ppm}$ : 53.4, 120.1, 128.8, 128.9, 129.0, 129.2, 129.5, 131.9, 133.3, 134.1, 134.8, 143.6, 144.1, 162.0, 
187.4. MS (m/z, rel. int.): 292(70\%, [M] $\left.]^{+}\right) ; 260\left(14 \%,\left[\mathrm{M}-\mathrm{CH}_{4} \mathrm{O}\right]^{+}\right) ; 231\left(30 \%,\left[\mathrm{M}-\mathrm{C}_{2} \mathrm{H}_{3} \mathrm{O}_{2}\right]^{+}\right)$;

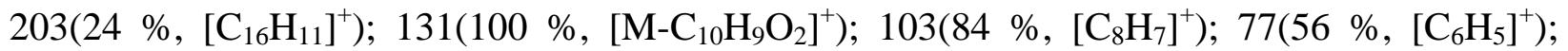
51(19\%, [C $\left.\left.\mathrm{C}_{4} \mathrm{H}_{3}\right]^{+}\right)$. Anal. Calcd. for $\mathrm{C}_{19} \mathrm{H}_{16} \mathrm{O}_{3}$ : C, 78.06; H, 5.52. Found: C, 78.36; H, 5.61.

Methyl (2Z,4E)-4-oxo-2,5-hexadienoate (5). IR (KBr, film, $\mathrm{cm}^{-1}$ ): 3010; 2998; 1747 (broad); 1433; 1348; 1212; 1095; 908; 769; 707. ${ }^{1} \mathrm{H}-\mathrm{NMR}\left(\mathrm{CDCl}_{3}\right) \delta \mathrm{ppm:} 3.76(\mathrm{~s}, 3 \mathrm{H}), 6.60\left(\mathrm{~d},{ }^{3} \mathrm{~J}(\mathrm{H}, \mathrm{H})\right.$ $=11.9 \mathrm{~Hz}, 1 \mathrm{H}), 7.13\left(\mathrm{~d},{ }^{3} \mathrm{~J}(\mathrm{H}, \mathrm{H})=11.9 \mathrm{~Hz}, 1 \mathrm{H}\right), 7.05-7.66(\mathrm{~m}, 7 \mathrm{H}) .{ }^{13} \mathrm{C}-\mathrm{NMR}\left(\mathrm{CDCl}_{3}\right) \delta \mathrm{ppm}$ : 52.1, 123.6, 129.2, 129.2, 131.9, 132.2, 133.5, 134.1, 143.6, 164.0, 188.3. MS (m/z, rel. int.):

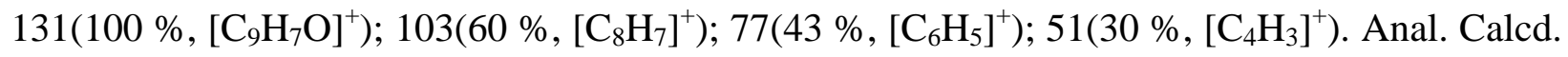
for $\mathrm{C}_{13} \mathrm{H}_{12} \mathrm{O}_{3}$ : C, 72.21; H, 5.59. Found: C, 71.94; H, 5.62.

Methyl (E)- 2-benzylidene-3-oxo-5-phenylpent-4-enoate (7). IR ( $\mathrm{KBr}$, film, $\mathrm{cm}^{-1}$ ): 3006; 1724 (broad); 1437; 1367; 1223; 1099; 893; 792; 699. ${ }^{1} \mathrm{H}-\mathrm{NMR}\left(\mathrm{CDCl}_{3}\right) \delta$ ppm: 1.92 (d, 3H), 3.81 (s, 3H), $5.92\left(\mathrm{~m},{ }^{4} \mathrm{~J}(\mathrm{H}, \mathrm{H})=1.5 \mathrm{~Hz}, 1 \mathrm{H}\right), 6.20\left(\mathrm{~m},{ }^{4} \mathrm{~J}(\mathrm{H}, \mathrm{H})=1.0 \mathrm{~Hz}, 1 \mathrm{H}\right), 7.11-7.43(\mathrm{~m}, 5 \mathrm{H}), 7.82(\mathrm{~s}$, $1 \mathrm{H}) .{ }^{13} \mathrm{C}-\mathrm{NMR}\left(\mathrm{CDCl}_{3}\right) \delta \mathrm{ppm}: 16.2,53.4,128.7,129.0,129.5,131.5,133.4,134.7,137.2$, 143.6, 161.9, 195.6. MS (m/z, rel. int.): 162(49\%, [M- $\left.\left.\mathrm{C}_{4} \mathrm{H}_{4} \mathrm{O}\right]^{+}\right) ; 131\left(100 \%,\left[\mathrm{C}_{9} \mathrm{H}_{7} \mathrm{O}\right]^{+}\right)$; 103(74\%, $\left.\left[\mathrm{C}_{8} \mathrm{H}_{7}\right]^{+}\right) ; 77\left(44 \%,\left[\mathrm{C}_{6} \mathrm{H}_{5}\right]^{+}\right) ; 51\left(24 \%,\left[\mathrm{C}_{4} \mathrm{H}_{3}\right]^{+}\right)$. Anal. Calcd. for $\mathrm{C}_{14} \mathrm{H}_{14} \mathrm{O}_{3}: \mathrm{C}, 73.03$; H, 6.13. Found: C, 73.30; H, 6.22.

The products of homocoupling $\mathbf{8}$ and $\mathbf{9}$ are known. ${ }^{6}$

\section{Iododestannylation reactions}

All the reactions were carried out following the same procedure. One experiment is described in detail to illustrate the method used.

Synthesis of methyl (Z)-3-iodopropenoate (11). To a solution of compound $\mathbf{1}$ (1 g, $1.66 \mathrm{mmol})$ in dry $\mathrm{CH}_{2} \mathrm{Cl}_{2}(7.5 \mathrm{~mL})$ under argon was added iodine $(0.46 \mathrm{~g}, 1.83 \mathrm{mmol})$. The mixture was stirred at room temperature for $30 \mathrm{~min}$ with monitoring of the reaction by TLC. Column chromatography on silica gel 60 of the crude product gave the oily iodovinyl compound $\mathbf{1 1}$ in quantitative yield $(0.35 \mathrm{~g}, 1.66 \mathrm{mmol})$ in the fraction eluted with hexane-ether $(98: 2){ }^{7}$ IR was the only spectroscopic data available. ${ }^{7 b}{ }^{1} \mathrm{H}-\mathrm{NMR}\left(\mathrm{CDCl}_{3}\right) \delta \mathrm{ppm}: 3.67(\mathrm{~s}, 3 \mathrm{H}) ; 6.85\left(\mathrm{~d},{ }^{3} \mathrm{~J}(\mathrm{H}, \mathrm{H})=\right.$ 10.0, $1 \mathrm{H}) ; 7.41\left(\mathrm{~d},{ }^{3} \mathrm{~J}(\mathrm{H}, \mathrm{H})=10.0 \mathrm{~Hz}, 1 \mathrm{H}\right) .{ }^{13} \mathrm{C}-\mathrm{NMR}\left(\mathrm{CDCl}_{3}\right) \delta \mathrm{ppm}: 51.3 ; 93.7 ; 129.7 ; 164.8$. MS (m/z, rel. int.): 212(34\%, [M] $\left.{ }^{+}\right) ; 127(2 \%,[\mathrm{I}]) ; 85\left(100 \%,[\mathrm{M}-\mathrm{I}]^{+}\right) ; 53\left(37 \%,\left[\mathrm{C}_{3} \mathrm{H}_{2} \mathrm{O}\right]^{+}\right)$; $26\left(15 \%,\left[\mathrm{C}_{2} \mathrm{H}_{4}\right]^{+}\right)$.

Similarly, iododestannylation of $\mathbf{2}$ and $\mathbf{1 0}$ leads quantitatively to the known methyl (Z)-2-iodo-3phenylpropenoate (12) ${ }^{8}$ and (Z)-1-iodo-1,2-diphenylethene (13), ${ }^{4 \mathrm{c}, 4 \mathrm{~d}}$ respectively.

Stille reactions between vinyl iodides and trineophylstannylvinyl compounds

All the reactions were carried out following the same procedure. One experiment is described in detail to illustrate the method used.

\section{Synthesis of methyl (E)-2-benzylidene-3-phenylbut-3-enoate (17). General method}

To a solution of vinyl iodide $12(0.76 \mathrm{~g}, 2.6 \mathrm{mmol})$ and vinylstannane 14 (1.61 g, $2.6 \mathrm{mmol})$ in dry DMF (12 mL) under argon atmosphere, $\mathrm{Pd}\left(\mathrm{PPh}_{3}\right)_{4}(0.26 \mathrm{mmol})$ and $\mathrm{CuI}(1.3 \mathrm{mmol})$ were added. The mixture was stirred at $60^{\circ} \mathrm{C}$ monitoring the progress of the reaction by TLC. The reaction mixture was treated with saturated aqueous $\mathrm{KF} 50 \%(12 \mathrm{~mL})$. The aqueous phase was separated and treated with diethyl ether ( $3 \times 4 \mathrm{~mL}$ ). The combined extracts were dried with 
anhydrous $\mathrm{MgSO}_{4}$, filtered, and the solvent eliminated under reduced pressure. The oily residue was purified by column chromatography on silica gel 60 (Hexane-Ether 97:3) to afford 17 (0.55 g, $1.61 \mathrm{mmol})$ in $62 \%$ yield. IR (KBr, film, $\left.\mathrm{cm}^{-1}\right)$ : 3060; 3029; 1712; 1634; 1491; 1164; 761; 695. ${ }^{1} \mathrm{H}-\mathrm{NMR}\left(\mathrm{CDCl}_{3}\right) \delta$ ppm: $3.6(\mathrm{~s}, 3 \mathrm{H}) ; 5.57\left(\mathrm{~d},{ }^{2} \mathrm{~J}(\mathrm{H}, \mathrm{H})=2.2 \mathrm{~Hz}, 1 \mathrm{H}\right) ; 5.61\left(\mathrm{~d},{ }^{2} \mathrm{~J}(\mathrm{H}, \mathrm{H})=2.2\right.$ $\mathrm{Hz}, 1 \mathrm{H}) ; 7.23$ (m, $10 \mathrm{H}) ; 7.67$ (s, $1 \mathrm{H}) .{ }^{13} \mathrm{C}-\mathrm{NMR}\left(\mathrm{CDCl}_{3}\right) \delta$ ppm: 53.6; 109.2; 126.1; 127.1; 127.3; 127.9; 128.7; 130.0; 133.6; 136.0; 139.7; 142.0; 165.6. MS (m/z, rel. int.): 264 (7 \%,

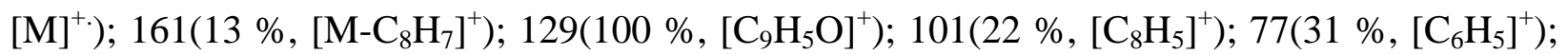
51 $\left(17 \%,\left[\mathrm{C}_{4} \mathrm{H}_{3}\right]^{+}\right)$. Anal. Calcd. for $\mathrm{C}_{18} \mathrm{H}_{16} \mathrm{O}_{2}$ : C, 81.79; H, 6.10. Found: C, 81.92; H, 6.08.

Under the same reaction conditions, starting from the apropriate vinyl iodides and vinylstannanes, the known methyl (2Z,4E)-4,5-diphenylpenta-2,4-dienoate (16) ${ }^{9}$ and dimethyl $(2 E, 4 E)$-4-benzylidenepent-2-enedioate (18) were obtained ${ }^{6 a}$

\section{Acknowledgements}

This work was supported by grants from CONICET (Ciudad de Buenos Aires, Argentina) and Universidad Nacional del Sur (Bahía Blanca, Argentina). Fellowhips from CONICET to PMF and DCG, and a travel grant to one of us (JCP) from the Alexander von Humboldt Foundation (Germany), are also gratefully acknowledged.

\section{References}

1. (a) Stille, J. K. Angew. Chem. Int. Ed. 1986, 25, 508. (b) Farina, V.; Krishnamurthy, V; Scott, W. J. Organic Reactions 1997, 50, 1. (c) Mitchell, T. N. Organotin Reagents in CrossCoupling, 1998, Chapter 4 In Metal-catalyzed Cross-coupling Reactions; Diederich, F., Stang, P. J., Eds.; Wiley-VCH: Weinheim, Germany. (d) Davies, A. Organotin Chemistry, 2004, VCH, Weinheim. (e) Dorrenbacher, S.; Kazmaier, U.; Ruf, S. Synlett 2006, 4, 547. (f) Kerr, D. J.; Metje, C.; Flynn, B. L., Chem. Commun., 2003, 12, 1380.

2. (a) Labadie, J. W.; Tuetin, D.; Stille, J. K., J. Org. Chem. 1983, 48, 4634. (b) Labadie, J. W.; Stille, J. K., J. Am. Chem. Soc. 1983, 105, 6129. (c) Milstein, D.; Stille, J. K. J. Am. Chem. Soc. 1978, 100, 3636. (d) Milstein, D.; Stille, J. K. J. Org. Chem. 1979, 44, 1613. (e) Kosugi, M.; Shimizu, Y.; Migita, T. Chem. Lett. 1977, 1423. (f) Kosugi, M.; Shimizu, Y.; Migita, T. J. Organomet. Chem. 1977, 129, C36. (g) Thibonnet, J.; Abarbri, M.; Parrain, J.L.; Duchêne, A. J. Org. Chem. 2002, 67, 3941. (h) Lerenbours, R.; Camacho-Soto, A.; Wolf, Ch. J. Org. Chem. 2005, 70, 8601. (i) Parrain, J.-L.; Duchêne, A.; Watrelot, S.; Quintard, J.-P. Tetrahedron Lett. 1993, 34, 5445. (j) Lee, K.; Gallagher, W. P.; Toskey, E. A. J. Organomet. Chem. 2006, 691, 1462. 
3. (a) Baraldi, G.; Bazzanini, R.; Bigoni, A.; Manfredini, S.; Simoni, D.; Spalluto, G., Synthesis, 1993, 1206. (b) Jung, J. H.; Chang, C.-J.; Smith, D. L.; McLaughlin, J. L.; Pummangura, S.; Chaichantipyuth, C.; Patarapanic, C., J. Nat. Prod., 1991, 54, 500.

4. (a) Dodero, V.; Koll, L.; Mandolesi, S.; Podestá, J. C. J. Organomet. Chem. 2002, 650, 173. (b) Dodero, V. I.; Koll, L. C.; Faraoni, M. B.; Mitchell, T. N.; Podestá, J. C. J. Org. Chem. 2003, 68, 10087. (c) Dodero, V. I.; Faraoni, M. B.; Gerbino, D. C.; Koll, L. C.; Zúñiga, A. E.; Mitchell, T. N.; Podestá, J. C. Organometallics 2005, 24, 1992. (d) Faraoni, M. B.; Dodero V. I.; Podestá, J. C. Arkivoc 2005, 88. (e) Faraoni, M. B.; Dodero, V. I.; Koll, L. C.; Zúñiga, A. E.; Mitchell, T. N.; Podestá, J. C. J. Organomet. Chem. 2006, 691, 1085.

5. Jung, M.; Light, L. E. Tetrahedron Lett. 1982, 23, 3851.

6. (a) Newman, M. S.; Cella, J. A. J. Org. Chem. 1974, 39, 2084. (b) Elbe, H.-L.; Köbrich, G. Chem. Ber. 1974, 107, 1654.

7. (a) Piers, E.; Wong, T.; Coish, P. D.; Rogers, C. Can. J. Chem. 1994, 72, 1816. (b) Topek, K.; Vsetecka, V.; Prochazka, M. Collect. Czech. Chem. Comm. 1978, 43, 2395.

8. Klein, J.; Levene, R. J. C. S., Perkin Trans. 2 1973, 1971.

9. Eberbach, W.; Burchardt, B. Chem. Ber. 1978, 111, 3665. 